\title{
Non-GIST Mesenchymal Tumors of the Gastrointestinal Tract
}

\section{Gastrointestinal Sistemin GIST Dışı Mezenkimal Tümörleri}

Meryem Ilkay Eren Karanis ${ }^{1}$, Ilknur Kucukosmanoglu ${ }^{1}$, Tugba Gunler ${ }^{1}$,

Yasar Unlu ${ }^{1}$,

Hande Koksal ${ }^{2}$

${ }^{1}$ University of Health Sciences, Konya Education and Research Hospital, Department of Pathology, Konya, Turkey, Turkey

${ }^{2}$ University of Health Sciences, Konya Education and Research Hospital, Department of General Surgery, Konya, Turkey

Geliş Tarihi/Received: 16 July 2020 Kabul Tarihi/Accepted: 12 November 2020

Address correspondence to: Meryem llkay Eren Karanis, Konya Education and Research Hospital, Department of Pathology, Konya, Turkey

e-mail:dr-ilkay@hotmail.com

\section{ORCID}

Meryem Ilkay Eren Karanis

https://orcid.org/0000-0002-1097-4592

Ilknur Kucukosmanoglu

https://orcid.org//0000-0002-5181-6152

Tugba Gunler

https://orcid.org/0000-0001-6319-7304

Yasar Unlu

https://orcid.org/0000-0002-3951-8881

Hande Koksal

https://orcid.org/0000-0002-9668-7913

\begin{abstract}
Öz
Amaç: Gastrointestinal stromal tümörler dışındaki gastrointestinal sistemin mezenkimal tümörleri nadirdir ve çoğu iyi huyludur. Bu çalışmanın amacı gastrointestinal sistemin gastrointestinal stromal tümör dışı mezenkimal tümörlerinin klinik ve patolojik özelliklerini ortaya koymaktır.

Hastalar ve Yöntem: 2008-2018 yılları arasında tüm gastrointestinal endoskopik ve cerrahi rezeksiyon materyalleri retrospektif olarak incelendi. Gastrointestinal stromal tümör dışındaki mezenkimal tümör tanısı alan olgular dahil edildi.

Bulgular: Yirmi dört lipom, on dört inflamatuar fibroid polip, altı leiomyom, dört lenfanjiyom, dört hemanjiyom, dört schwannom, iki nöroma, iki malign melanom, bir leiomyosarkom, bir granüler hücreli tümör ve bir Kaposi sarkomu saptandı. Olguların ortanca yaşları 61 (29-87), ortanca tümör boyutu 1.5 $\mathrm{cm}(0.2-14)$ idi. Otuz yedi olgu (\% 58,7) kadın, 26 olgu (\% 41,3) erkekti. Bu tümörler spesifik olmayan semptomlara neden oldular. Benign tümörlerde eksizyon sonrası patolojik tanıya bakılmaksızın nüks veya metastaz saptanmadı.

Sonuç: Gastrointestinal sistemin gastrointestinal stromal tümör dışı mezenkimal tümörleri her yașta görülebilen ve sıklıkla kadınlarda izlenen, çoğunlukla küçük ve iyi huylu tümörlerdir. En yaygın olanları lipomlar ve inflamatuar fibroid poliplerdir. Mide tümörlerinin çoğu dispeptik şikayetlere, barsak tümörleri de karın ağrısı, bulantı veya kusmaya neden olurlar. Ayrıca bağırsak tümörlerinin bazıları akut ve kronik kanama, obstrüksiyon, perforasyon, volvulus veya intussussepsiyon gibi ciddi, hatta ölümcül klinik durumlara yol açarlar. İyi huylu tümörlerin tedavisi için eksizyon yeterlidir, nüks veya metastaz göstermezler.
\end{abstract}

Anahtar Kelimeler: Gastrointestinal mezenkimal tümör, non-GIST, lipom, inflamatuar fibroid polip, kaposi sarkomu, schwannom.

\section{Abstract}

Aim: Mesenchymal tumors of the gastrointestinal tract other than gastrointestinal stromal tumors are rare and most of them are benign. The aim of this study to reveal the clinical and pathological features of nongastrointestinal stromal tumor mesenchymal tumors of the gastrointestinal tract.

Patients and Methods: All gastrointestinal endoscopic and surgical resection materials, between 20082018, were retrospectively reviewed. Cases diagnosed with mesenchymal tumor other than gastrointestinal stromal tumors were included.

Results: Twenty four lipomas, fourteen inflammatory fibroid polyps, six leiomyomas, four lymphangiomas, four hemangiomas, four schwannomas, two neuromas, two malignant melanomas, one leiomyosarcoma, one granular cell tumor and one Kaposi sarcoma were detected. The median ages of the cases were 61 years (29-87), the median tumor size was $1.5 \mathrm{~cm}(0.2-14)$. Thirty seven $(58.7 \%)$ cases were female and 26 $(41.3 \%)$ were male. They caused nonspecific symptoms. No recurrence or metastasis was detected after excision in benign tumors regardless of the pathological diagnosis.

Conclusion: Non-gastrointestinal stromal tumor mesenchymal tumors of the gastrointestinal tract are mostly small and benign tumors that can be seen at any age and are frequently seen in women. The most common ones are lipomas and inflammatory fibroid polyps. Most gastric tumors cause dyspeptic complaints and intestinal tumors cause abdominal pain, nausea or vomiting, as well as some of the intestinal tumors lead to serious, even fatal clinical situations such as acute and chronic bleeding, obstruction, perforation, volvulus or intussusception. For benign tumors' treatment, excision is sufficient, they do not exhibit recurrence or metastasis.

Key words: Gastrointestinal mesenchymal tumor, non-GIST, lipoma, inflammatory fibroid polyp, kapos sarcoma, schwannoma
Cite this article as: Eren Karanis MI, Kucukosmanoglu I, Gunler T, Unlu Y, Koksal H. Non-GIST Mesenchymal Tumors of the Gastrointestinal Tract. Selcuk Med J 2020;36(4): 325-332

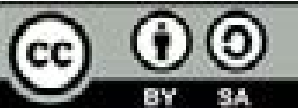

Disclosure: None of the authors has a financial interest in any of the products, devices, or drugs mentioned in this article. The research was not sponsored by an outside organization. All authors have agreed to allow full access to the primary data and to allow the journal to review the data if requested. 


\section{INTRODUCTION}

The vast majority of tumors in the gastrointestinal tract are epithelial tumors. Apart from epithelial tumors, lymphomas and mesenchymal tumors are also seen in gastrointestinal tract. The most common mesenchymal tumors of the gastrointestinal tract are gastrointestinal stromal tumors (GIST) and nonGIST mesenchymal tumors of the gastrointestinal tract (NGMTGT) are rare. These tumors originate from mesodermal tissues and are similar to their counterparts that seen in soft tissue. NGMTGT, which constitute a wide spectrum, originate from muscle tissue, nerve tissue, adipose tissue, connective tissue and vascular elements (1).

Both benign and malignant non-GIST mesenchymal tumors can be seen in the gastrointestinal tract, but most of them are benign and small in size. NGMTGT are usually detected incidentally during endoscopic examination. Although these tumors are rare, their incidence have been increasing in recent years with the widespread using of endoscopic applications. Eventhough NGMTGT are generally asymptomatic, they can cause various dyspeptic complaints and gastrointestinal bleeding, or they may present with a palpable mass (2).

In this study, we aimed to reveal the clinical and pathological features of NGMTGT and treatment methods of these tumors.

\section{PATIENTS AND METHODS}

Ethical approval was obtained from the Ethics Committee of KTO Karatay University, Faculty of Medicine (2019/0020) for the study. The study was carried out in accordance with the Helsinki Declaration principles. In our study, research and publication ethics were followed. As the study was a retrospective study, the ethics committee decided that an informed consent form was not required.

All esophagogastroduodenoscopic and colonoscopic biopsy materials, partial or total esophagus, gastric and intestinal resection materials, which were examined at the Pathology Clinic of Konya Education and Research Hospital between 1 August 2008 and 1 August 2018, were retrospectively reviewed. Cases diagnosed as mesenchymal tumor other than GIST in the gastrointestinal tract were included in the study. Clinical and pathological informations such as age, gender, and complaints during admission of the patients, localization, size, and pathological diagnosis of the tumors, diagnostic tools, treatment methods and follow-up informations were obtained from patient files.

The statistical analyses were performed using SPSS 15.0 for Windows (SPSS, Chicago, IL, USA). The Shapiro-Wilk test was used for examining the continuous variables with normal and abnormal distributions, while the one-way analysis of variance (ANOVA) was used for the normally distributed continuous variables. The Kruskal-Wallis test was used for the abnormally distributed continuous variables. When the Kruskal-Wallis test indicated statistically significant differences, the causes of those differences were determined by using a Bonferroniadjusted Mann-Whitney $U$ test. The nominal variables were analyzed using Pearson's chi-square or Fisher's exact test, when applicable. The continuous variables were presented as the mean \pm standard deviation (SD) or median (min-max), and the categorical variables were presented as the number of cases and percentage. For all possible multiple comparisons, the Bonferroni-adjustment was performed to control the type I errors. Statistical significance was set at $p<$ 0.05 .

\section{RESULTS}

In the gastrointestinal tract including the esophagus, stomach, small intestine, appendix and large intestine 63 NGMTGT were detected. The ages of the patients ranged from 29 to 87 years (median, 61.0 years). The median tumor size was $1.5 \mathrm{~cm}$ and ranged from 0.2 to $14 \mathrm{~cm}$. Thirty seven $(58.7 \%)$ of the cases were female and $26(41.3 \%)$ were male. Twenty four lipomas, 14 inflammatory fibroid polyps (IFP), six leiomyomas, four lymphangiomas, four hemangiomas, four schwannomas, two neuromas, two malignant melanomas, one leiomyosarcoma, one granular cell tumor and one Kaposi sarcoma were detected (Figure1-8). The distribution of the pathological

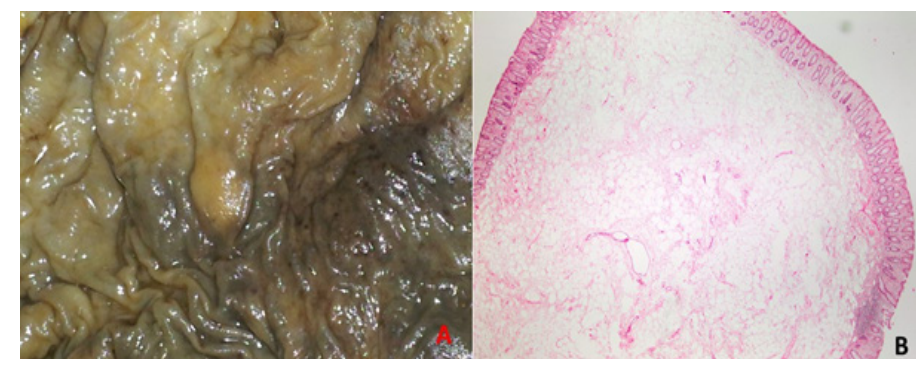

Figure 1. Submucosal lipoma localized in the colon. A-Macroscopically; yellow colored, polypoid lesion. BMicroscopically; Tumoral lesion consisting of mature adipose tissue under the colon mucosa. HEx20 
Table 1. The distribution of the pathological diagnoses of NGMTGT

\begin{tabular}{lcc}
\hline Pathological Diagnosis & Number of Cases $(\mathbf{n})$ & Percentage of Cases (\%) \\
\hline Lipoma & 24 & 38.0 \\
Inflammatory fibroid polyp & 14 & 22.2 \\
Leiomyoma & 6 & 9.5 \\
Hemangioma & 4 & 6.4 \\
Lymphangioma & 4 & 6.4 \\
Schwannoma & 4 & 6.4 \\
Neuroma & 2 & 3.2 \\
Malignant melanoma & 2 & 3.2 \\
Leiomyosarcoma & 1 & 1.6 \\
Kaposi sarcoma & 1 & 1.6 \\
Granular cell tumor & 1 & 1.6 \\
\hline
\end{tabular}

Table 2. The distribution of the localization of NGMTGT

\begin{tabular}{lcc}
\hline Localization of the Tumor & Number of Cases (n) & Percentage of Cases (\%) \\
\hline Large intestine & 38 & 60.3 \\
Stomach & 17 & 27.0 \\
Small intestine & 5 & 7.9 \\
Appendix & 2 & 3.2 \\
Esophagus & 1 & 1.6 \\
\hline
\end{tabular}

diagnoses of the cases are shown in Table 1, and the distribution of the localization of tumors are shown in Table 2 . The cases were usually detected incidentally by surgical resection performed for various reasons or by endoscopic examination which were performed for dyspeptic complaints, abdominal pain, constipation, iron deficiency anemia and defecation complaints such as pain and/or bleeding during defecation or palpable mass after defecation. The symptoms duiring admission are shown in Table 3 and the clinical and pathological features of NGMTGT are shown in table 4. Thirty nine $(61.9 \%)$ of the cases were diagnosed by endoscopic examination and $24(38.1 \%)$ were diagnosed by surgical resection material. Except for Kaposi sarcoma, all NGMTGT were excised; 38 $(60.3 \%)$ of them were excised endoscopically and 24 $(38.1 \%)$ of them were excised surgically.

All 24 lipomas were localized in the large intestine, five in the cecum, three in the ascending colon, one in the hepatic flexure, one in the transverse colon, one in the splenic flexure, one in the descending colon, six in the sigmoid colon, and six in the rectum. Thirteen of the cases were female and 11 were male. The ages of the cases ranged between 38 and 85 years, and the size of the tumors ranged from $0.2 \mathrm{~cm}$ to 7 $\mathrm{cm}$. Nine of the lipomas were diagnosed by surgical resection material and 15 by colonoscopy. Lipomas were multiple in three cases. Lipomas were detected

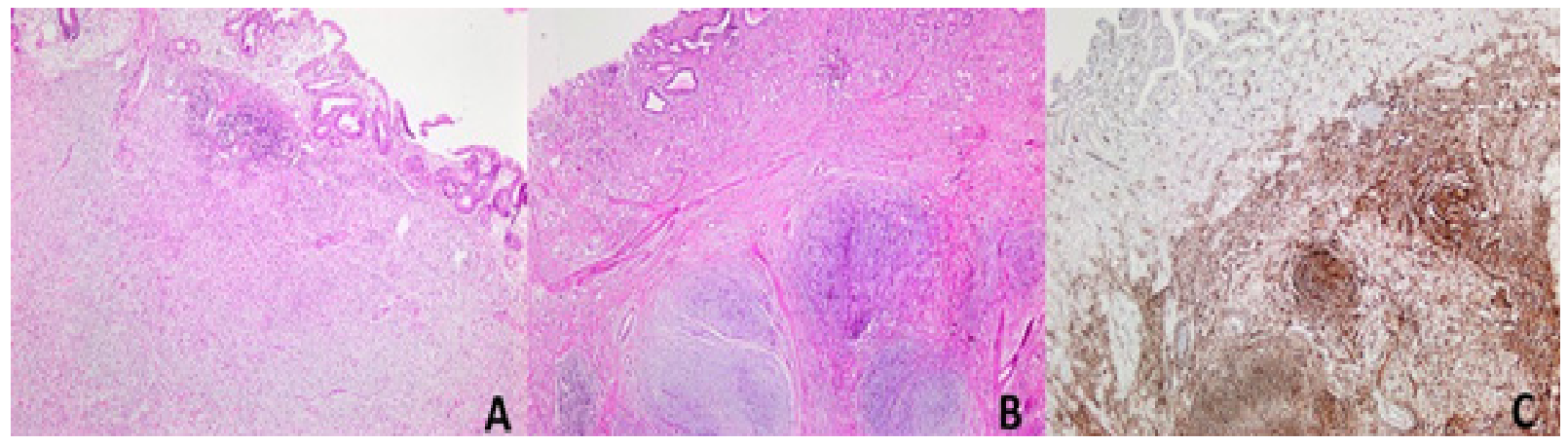

Figure 2. Gastric inflammatory fbroid polyp: A- Well marginated but nonencapsulated tumor composed of bland spindle cells and dense eosinophils, also lymphocytes, plasma cells, mast cells, and histiocytes. HEx50 B- 'Onion skin' arrangement of spindle cells around vessels. HEx100 C- Immunohistochemical CD34 positivity in spindle cells. CD34x100, 
Table 3. The distribution of the symptoms of NGMTGT

\begin{tabular}{lcc}
\hline Symptoms of the cases & Number of Cases (n) & Percentage of Cases (\%) \\
Dyspeptic complaints & 16 & 25.4 \\
Abdominal pain & 14 & 22.2 \\
Iron deficiency anemia & 9 & 14.3 \\
Obstruction complaints & 4 & 6.3 \\
Lower GIT bleeding & 3 & 4.8 \\
Defecation complaints & 3 & 4.8 \\
Constipation & 2 & 3.2 \\
Other & 12 & 1.0 \\
\hline
\end{tabular}

incidentally in the segmental colon resection materials that were performed due to colon adenocarcinoma in three cases and appendiceal mucinous tumor in one case. Lipoma caused volvulus in one case and intussusception in two cases, and these three cases were admitted to the emergency department with complaints of obstruction such as abdominal pain, lack of gas-stool, nausea and vomiting.

Fourteen IFP were detected and of the IFP ten $(71.4 \%)$ were female and four $(28.6 \%)$ were male. The ages of the cases ranged between 29 and 87 years and the sizes of the tumors were between 0.5 and 14 $\mathrm{cm}$. Only one $(7.1 \%)$ of the 14 IFP was localized in the ileum, all of the remaining $13(92.9 \%)$ IFP were observed in the stomach and all of them were in the antrum. IFP in the ileum was incidentally detected in the surgical resection material performed due to the mixed adenoneuroendocrine carcinoma, and one of the IFP located in the stomach incidentally detected during control endoscopic examination due to previous gastric adenocarcinoma. Twelve $(85.7 \%)$ of the IFP were identified during esophagogastroduedenoscopic examination applied for dispeptic complaints.

Among four hemangiomas two of them were localized in the jejunum, one in the ileum and one in the descending colon. One of the hemangioma was incidentally detected in the jejenum resection

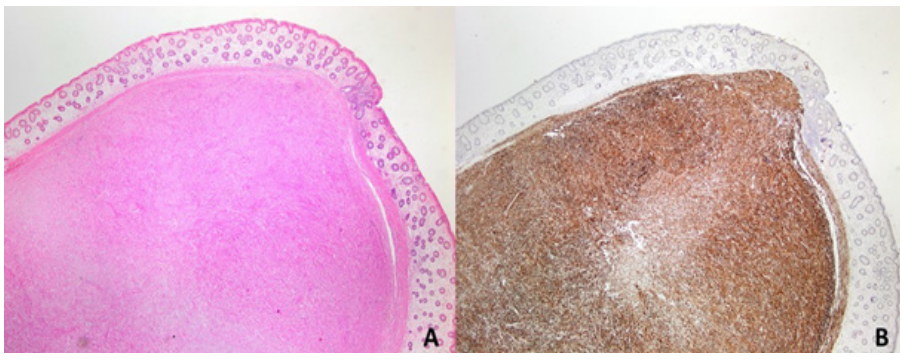

Figure 3. Submucosal leiomyoma localized in the colon. ATumoral lesion consisting of spindle cells that form fascicles under the colon mucosa. HEx20 B-Immunohistochemical Desmin positivity in spindle cells. Desminx20 material performed due to adenocarcinoma and the other hemangioma localized in the jejenum caused bowel perforation. Hemangiomas that were located in the ileum and descending colon were detected endoscopically in patients who were investigated for iron deficiency anemia. Lymphangioma cases' ages ranged from 45 to 62 years and one of them was male and three were female. Two of these tumors were localized in the rectum and two in the anal canal and ranging from $0.7 \mathrm{~cm}$ to $5.5 \mathrm{~cm}$ in diameter. The tumor with a diameter of $5.5 \mathrm{~cm}$ was surgically excised while others were excised endoscopically.

Five of the leiomyomas were localized in the colon and one in the jejunum. The leiomyoma localized in the jejunum caused recurrent intussusception and was diagnosed from surgical resection material. Those localized in the colon were observed during the colonoscopic examination, in which the etiology of abdominal pain was investigated. Leiomyosarcoma was observed in a 54-year-old male. It was $7 \mathrm{~cm}$ in diameter and was detected in the total colectomy specimen performed in the patient with adenomatous polyposis coli.

Three of the schwannoma cases were female and one was male, and their ages ranged between 31

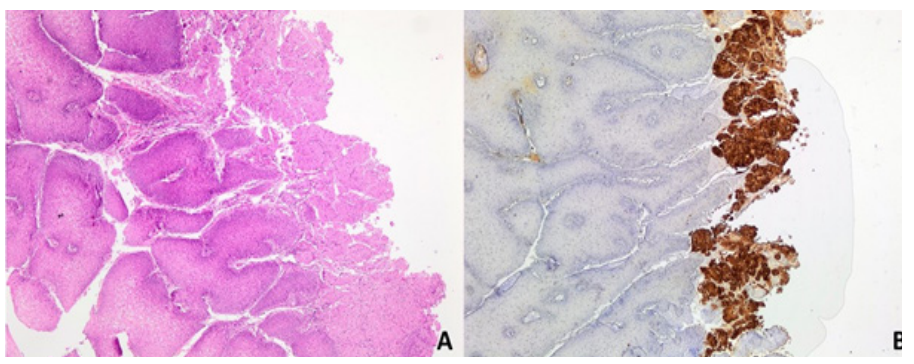

Figure 4. Granular cell tumor localized in the esophagus. A- Tumoral lesion consisting of uniform cells with large eosinophilic granular cytoplasm under the nonkeratinized squamous epithelium in papillary configuration. HEx100 B- Immunohistochemical S-100 positivity in tumor cells. S- $100 \times 100$ 
Table 4. The distribution of the symptoms of NGMTGT

\begin{tabular}{|c|c|c|c|c|c|}
\hline Pathological diagnosis (n) & $\begin{array}{l}\text { Age Median } \\
(\min -\max )\end{array}$ & $\begin{array}{l}\text { Gender } \\
\text { Female/male }\end{array}$ & $\begin{array}{l}\text { Size (cm) } \\
\text { Median } \\
(\text { min-max) }\end{array}$ & $\begin{array}{l}\text { Most common } \\
\text { localization }\end{array}$ & $\begin{array}{l}\text { Most common } \\
\text { symptom }\end{array}$ \\
\hline Lipoma $(n=24)$ & $63(38-85)$ & $13 / 11$ & $1.5(0.2-7)$ & Large intestine & $\begin{array}{l}\text { Abdominal pain/Iron } \\
\text { deficiency anemia }\end{array}$ \\
\hline Inflammatory fibroid polyp $(n=14)$ & $62(29-87)$ & $10 / 4$ & $1.4(0.5-14)$ & Stomach & Dyspeptic complaint \\
\hline Leiomyoma $(n=6)$ & $53(52-84)$ & $3 / 3$ & $1.5(0,3-4)$ & Large intestine & Abdominal pain \\
\hline Hemangioma $(n=4)$ & $67(46-77)$ & $2 / 2$ & $1.5(1-3)$ & Small intestine & Iron deficiency anemia \\
\hline Lymphangioma $(n=4)$ & $59(45-62)$ & $3 / 1$ & $1.5(0.7-5.5)$ & Large intestine & $\begin{array}{l}\text { Abdominal pain/Defecation } \\
\text { complaints }\end{array}$ \\
\hline Schwannoma $(n=4)$ & $43(31-74)$ & $3 / 1$ & $3.5(1.8-4.5)$ & Stomach & Dyspeptic complaint \\
\hline Neuroma $(n=2)$ & $56-80$ & $1 / 1$ & $0.5-0.5$ & Appendix & Incidentally \\
\hline Malignant melanoma $(n=2)$ & $47-64$ & $1 / 1$ & $3-7$ & Large intestine & $\begin{array}{l}\text { Abdominal pain/Iron } \\
\text { deficiency anemia }\end{array}$ \\
\hline Leiomyosarcoma $(n=1)$ & 54 & $0 / 1$ & 7 & Large intestine & Incidentally \\
\hline Kaposi sarcoma $(n=1)$ & 85 & $1 / 0$ & 1.5 & Stomach & Dyspeptic complaint \\
\hline Granular cell tumor $(n=1)$ & 32 & $0 / 1$ & 1 & Esophagus & Dyspeptic complaint \\
\hline
\end{tabular}

and 74 years. Three schwannomas were localized in the stomach and one schwannoma in the colon. Schwanoma localized in the colon was $1.8 \mathrm{~cm}$ in diameter and those localized in the stomach were 3.5 $\mathrm{cm}$ and $4.5 \mathrm{~cm}$ in the corpus and $4.5 \mathrm{~cm}$ in the antrum. Two neuromas were both incidentally detected in appendectomy materials. Appendectomy was performed in one of the case due to acute appendicitis and in the other performed during inguinal hernia repair surgery.

The cases of malignant melanoma were 64 and 47 years old, $7 \mathrm{~cm}$ and $3 \mathrm{~cm}$ in diameter, respectively, and both were surgically excised. The case, who was defined as Kaposi sarcoma, was a 85-year-old female

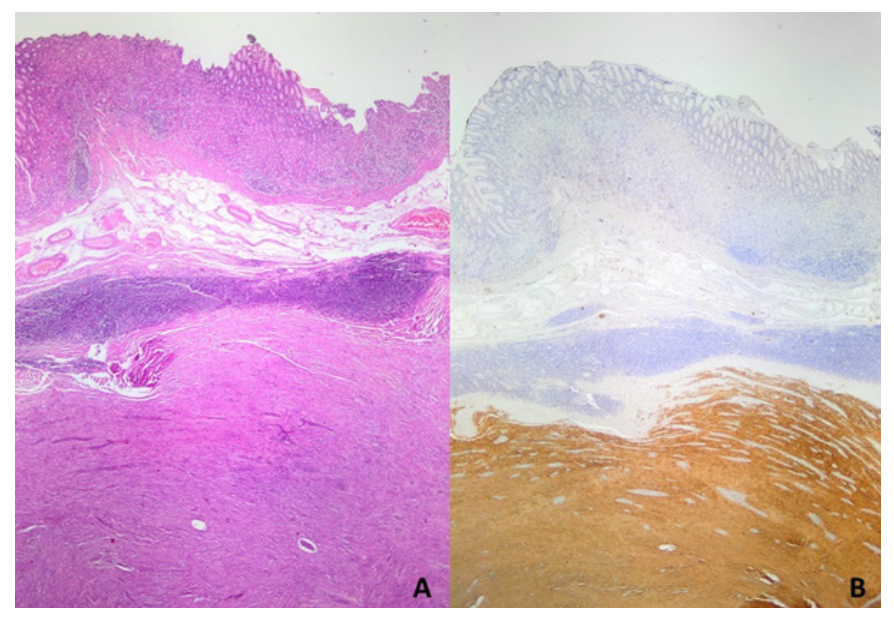

Figure 5. Gastric schwannoma: A- Well circumscribed and non-capsular tumor composed of spindle cells and surrounded by a lymphoid cuff. HEx20 BImmunohistochemical S-100 positivity in tumor cells. S-100x20 and tumor was detected during endoscopy that was applied due to dyspeptic complaints.

Immunohistochemical stains were applied to all cases for differential diagnosis except lipomas. Granular cell tumor, schwanomas and neuromas were S100, hemangiomas were CD34, lymphangiomas were CD31 and D2-40, Kaposi sarcoma was HHV8, malignant melanomas were $\mathrm{S} 100$ and Melan-A, leiomysarcoma and leiomyomas were Desmin, IFP were CD34 positive. DOG1 and CD117 were negative in all cases that applied for differential diagnosis of GIST.

Five of our cases who were diagnosed as benign NGMTGT were died within 3-11 months after diagnosis, three of them were died due to myocardial infarction and two were due to chronic obstructive pulmonary disease. The patient with a $7 \mathrm{~cm}$ diameter lipoma who underwent segmental intestinal resection due to intussusception was died in the postoperative period. Seven benign NGMTGT

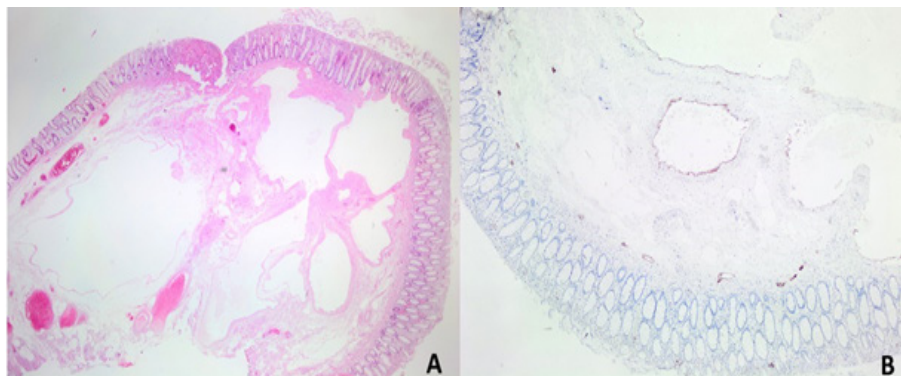

Figure 6. Submucosal lymphangioma localized in the colon: A- Tumor formed by dilated lymphatics. HEx20. BImmunohistochemical D2-40 positivity in dilated lymphatics. D2-40x100 


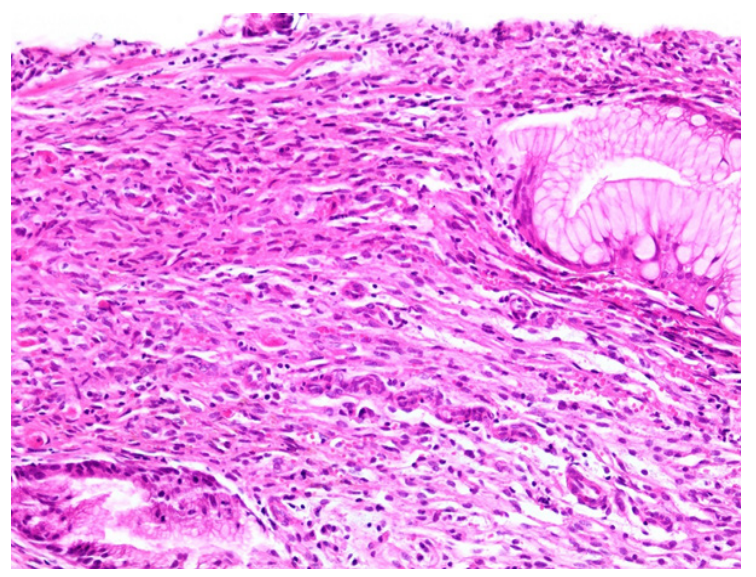

Figure 7. Gastric Kaposi sarcoma: Tumor composed of intersecting fascicles of uniform spindle cells, slit-like spaces and intervening eritrocytes, among gastric glands. HEx200

cases were lost duiring follow-up. The median followup for our 46 remaining benign NGMTGT cases were 56 (range 21-118) months, and no recurrence or metastasis was detected in any of them regardless of the pathological diagnosis. The case of Kaposi sarcoma died 13 months after diagnosis, the case of leiomyosarcoma died 34 months after diagnosis and cases of malignant melanoma died three and seven months after diagnosis.

\section{DISCUSSION}

Most NGMTGT are benign and small tumors (1). In our 64 -case series, $93.75 \%$ of cases consisted of benign tumors and we detected only 4 malignant tumors. The median size of the NGMTGT were 1.5 $\mathrm{cm}$ and $78.12 \%$ of the tumors were less than $2 \mathrm{~cm}$.

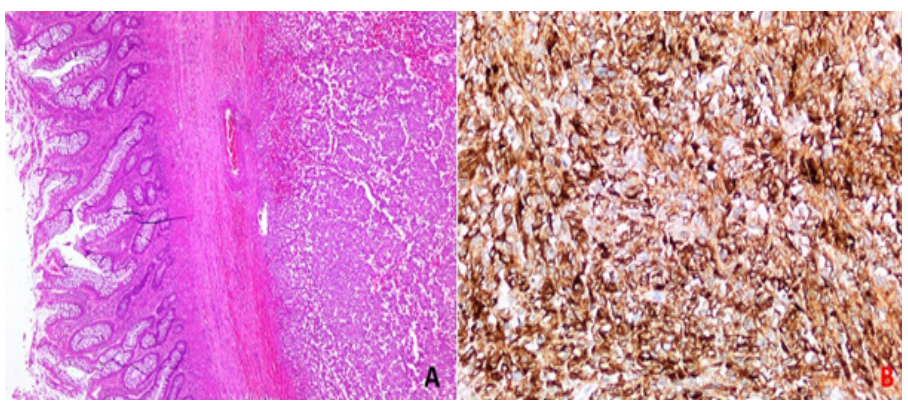

Figure 8. Malign melanoma: A- Tumor that composed of round pleomorphic cells formed nests and sheets in the submucosal colonic localization. HEx50 BImmunohistochemical Melan A positivity in tumor cells. Melan Ax100
Therefore, a considerable part of NGMTGT in our series consists of benign and small tumors.

The most common NGMTGT in biopsy materials are lipomas and vascular lesions (1). Lipomas are benign tumors consisting of mature adipose tissue, usually located submucosal in gastrointestinal tract (3). Lipomas of the gastrointestinal tract are most frequently observed in the colon, less frequently in the small intestine, and rarely in the stomach and esophagus (4-6). Lipomas in the colon are mostly localized in the right colon, and frequently in the cecum. Gastrointestinal lipomas tend to be more frequent in women and are most commonly detected in the fifth and sixth decades of life, but can be seen at any age, even in children $(6,7)$. In accordance with the literature; the most common NGMTGT in our series were lipomas, all of which were localized in the colon. Women were slightly more effected, the median age of the cases was 63 , and the ages of the cases ranged from 38 to 85 years. Unlike the literature, we observed lipomas most frequently in the left colon. Twelve lipomas, 11 of which were in the rectosigmoid region and one in the descending colon, were localized in the left colon and they were $50 \%$ of the lipomas in our series. Nevertheless, among the 9 lipomas observed in the right colon, five were localized in the cecum. Colon lipomas are usually benign and asymptomatic and are incidentally detected during colonoscopy, surgery or autopsy. However, large lipomas can be symptomatic and cause abdominal pain, bleeding, obstruction and intussusception (8). Colon lipomas can be resected endoscopically or surgically. It is suggested that large and symptomatic lipomas should be resected especially surgically (9). Four of our cases were diagnosed during surgery due to malignancy and one due to acute appendicitis. The lipomas caused invagination in two cases and volvulus in one case, and the diameters of these tumors were 7 $\mathrm{cm}, 5.3 \mathrm{~cm}$ and $3.2 \mathrm{~cm}$, respectively. Lipomas caused bleeding in the lower gastrointestinal tract in 3 cases. The remaining tumors presented with nonspecific complaints such as abdominal pain, constipation, iron deficiency anemia and were diagnosed during the colonoscopy. The 15 lipomas were endoscopically, nine were surgically resected and the largest lipoma which were endoscopically resected was $2 \mathrm{~cm}$ in diameter. In addition, lipomas were multiple in three cases and one of them had lower gastrointestinal tract bleeding and the other had iron deficiency anemia whereas one caused obstruction.

IFP is a rare benign tumor. Although it was 
previously thought to be a reactive process, recently the platelet derived growth factor alpha (PDGFRA) mutation has been described and it is recognized to be a real neoplasia (10). It is slightly more common in female (11). IFP often occurs in the sixth and seventh decades of life and most commonly encountered in the gastric antrum, followed by the small intestine, but it can occur anywhere in the gastrointestinal tract. Depending on its localization and size, it may be asymptomatic or symptomatic, and can cause abdominal pain, nausea, bleeding, even obstruction or weight loss (12). In Japan cases, association of IFP with gastric dysplasia/carcinoma has been reported (13). The second common NGMTGT in our series was IFP. $92.85 \%$ of our cases were localized in the gastric antrum and $71.42 \%$ of the patients were female. In one of our cases, IFP was detected with gastric adenocarcinoma. IFPs were usually encountered during endoscopy, but they can also be detected by surgical resection. Generally, they are single lesions with diameters of $2-5 \mathrm{~cm}$ (14). IFPs are well marginated but nonencapsulated tumors which were composed of bland spindle cells that often exhibit 'onion skin' arrangement around vessels. These tumors characteristically contain dense eosinophils, but there may also be lymphocytes, plasma cells, mast cells, and histiocytes. The spindle cells of IFP are characteristically CD34 positive, which may cause them to confuse with GIST, but they are negative with CD117 and DOG-1 (10).

Hemangiomasare raretumors in thegastrointestinal tract, and are most frequently encountered in the small intestine, especially in jejunum and constitute $10 \%$ of benign tumors of small intestine. They can be seen at any age and most patients present with evidence of acute or chronic gastrointestinal bleeding (15). Hemangiomas are generally seen as pedunculated polypoid mass, red or bluish in color, and they can be solitary, multiple or diffuse (16). In three of our four gastrointestinal hemangiomas, the tumor was localized in the small intestine and in two of them were in the jejunum. Iron deficiency anemia is presenting symptoms in two of the cases, indicating chronic bleeding. In one case, hemangioma caused perforation in the jejunum. Lymphangiomas, benign tumors formed by dilated lymphatic, can occur anywhere in the gastrointestinal tract, but mostly seen in colon. They are usually small tumors detected incidentally, and sometimes they can be detected as large masses and may be symptomatic. Gastrointestinal tract lymphangiomas may be seen at any age but majority of the patients are between 40 and 70 years old with a female predominance (17). $75 \%$ of the gastrointestinal lymphangiomas that we detected were female and tumors were smaller than 2 $\mathrm{cm}$ in diameter and all cases were between the ages of $40-70$ years.

Gastrointestinal leiomyomas originate from muscularis mucosa or muscularis propria. They are mostly seen in the esophagus, after the esophagus the most commonly involved site is colon, involvement of the stomach and the small intestine are rare (18). Leiomyomas are well-circumscribed tumors, consisting of bland spindle cells with fascicular growth patern. There can be minimal cytological atypia, mitotic activity is absent or low, and no necrosis is seen. Characteristically, they express immunohistochemical SMA and Desmin. They can be distinguished from GISTs by immunohistochemical SMA and desmin positivity, as well as CD117 and DOG-1 negativity, and from leiomyosarcoma which can be seen rarely in the gastrointestinal tract by evaluation of atypia, mitosis and necrosis. One of the leiomyoma that we detected were in the small intestine, the remaining five $(83.33 \%)$ leiomyomas were localized in the colon. In addition, the only leiomyosarcoma that we diagnosed was also in the colon.

Schwannomas are rarely seen NGMTGT and can be seen anywhere in the gastrointestinal tract, but mostly occur in the stomach and following that colon is the second frequent localization. They show a female predominance and usually occur in the sixth decade of life (19). They are usually asymptomatic and detected incidentally, sometimes they can cause nonspecific symptoms such as bleeding or abdominal pain. Gastrointestinal schwannomas exhibit different pathological features from schwannomas that are seen in the santral nervous system and soft tissue. Characteristically they are well circumscribed and noncapsular tumors, and can be plexiform. These tumors have a rubbery and yellow-white cut section and frequently surrounded by a lymphoid cuff (20). It is quite difficult to distinguish gastrointestinal schwannomas clinically, radiologically and even pathologically from GISTs. Since the schwannomas are benign tumors and do not show malignant transformation, surgical resection is sufficient for their treatment and there is no need for additional treatment. Therefore, it is very important to separate schwannomas from GISTs. Immunhistochemical evaluation is very important in distinguishing these two entities, and schwannomas show strong S100 and SOX-10 immunoreactivity, 
while CD117 and DOG-1 are negative unlike GIST $(21,22)$.

\section{CONCLUSION}

NGMTGTs are mostly small and benign tumors that can be seen at any age and are frequently seen in women. The most common NGMTGT are lipomas, and these occur frequently in the colon, in our experience, mostly in the left colon. According to our findings, the second common NGMTGT is IFP, and they are mostly localized in the gastric antrum. NGMTGT can be asymptomatic and may appear incidentally during endoscopy or in the surgical resection materials. On the other hand most gastric NGMTGT cause dyspeptic complaints and many of the intestinal NGMTGT can cause nonspecific complaints such as abdominal pain, nausea or vomiting, as well as some of the intestinal NGMTGT lead to serious, even fatal clinical situations such as acute and chronic bleeding, obstruction, perforation, volvulus or intussusception. NGMTGT may accompany malignancies, but they do not become malignant. For their treatment, excision is sufficient, they do not require additional treatment, they do not exhibit recurrence or metastasis.

Conflict of interest: Authors declare that there is no conflict of interest between the authors of the article.

Financial conflict of interest: Authors declare that they did not receive any financial support in this study.

Address correspondence to: Meryem Illkay Eren Karanis, Konya Education and Research Hospital, Department of Pathology, Konya, Turkey

E-mail: dr-ilkay@hotmail.com

Phone number: +903322210000

\section{REFERENCES}

1. Doyle LA, Hornick JL. Mesenchymal tumors of the gastrointestinal tract other than GIST. Surgical Pathology 2013;6(3):425-73.

2. Diaconescu MR, Diaconescu S. Mesenchymal (nonepithelial) "non-GIST" tumors of the digestive tract. Chirurgia (Bucur) 2012;107(6):742-50.

3. Noda H, Ogasawara N, Tamura $\mathrm{Y}$, et al. Successful endoscopic submucosal dissection of a large terminal ileal lipoma. Case Rep Gastroenterol 2016;10(3):506-11.

4. Yu HG, Ding YM, Tan S, et al. A safe and efficient strategy for endoscopic resection of large, gastrointestinal lipoma. Surg Endosc 2007;21:265-9.

5. Pagaro PM, Deshpande A. Lipoma of small intestine. Med J DY Patil Vidyapeeth 2015;8(4):525.

6. Zameer M, Kanojia RP, Rao KLN, et al. Gastric lipoma. J Indian Assoc Pediatr Surg 2010;15(2):64.

7. Jiang L, Jiang LS, Li FY, et al. Giant submucosal lipoma located in the descending colon: A case report and review of the literature. World J Gastroenterol 2007;13(42):5664.

8. M'rabet S, Jarrar MS, Akkari I, et al. Colonic intussusception caused by a sigmoidal lipoma: A case report. International Journal Of Surgery Case Reports 2018;50:1-4.

9. Crocetti D, Sapienza P, Sterpetti AV, et al. Surgery for symptomatic colon lipoma: A systematic review of the literature. Anticancer Research 2014;34(11):6271-6.

10. Plesec TP. Gastrointestinal mesenchymal neoplasms other than gastrointestinal stromal tumors: Focusing on their molecular aspects. Pathology Research International 2011;2011:952569.

11. Romano-Munive AF, Barreto-Zuñiga R, Rumoroso-García $\mathrm{JA}$, et al. Inflammatory fibroid polyp of the gastrointestinal tract: 10 years of experience at the Instituto Nacional de Ciencias Médicas y Nutrición Salvador Zubirán. Revista de Gastroenterología de México (English Edition) 2016;81(3):134-40.

12. Pinto-Pais $T$, Fernandes $S$, Proença $L$, et al. A large gastric inflammatory fibroid polyp. GE Port J Gastroenterol 2015;22(2):61-4.

13. Hasegawa T, Yang P, Kagawa N, et al. CD34 expression by inflammatory fibroid polyps of the stomach. Mod Pathol 1997;10(5):451-6.

14. Wronecki J, Błaszkiewicz A, Swatek J, et al. Inflammatory fibroid polyp in the antrum co-occurring with adenomatous polyp in the ascending colon. Prz Gastroenterol 2018;13(4):340.

15. Yoo S. Gl-associated hemangiomas and vascular malformations. Clin Colon Rectal Surg 2011;24(03):193-200.

16. Levy AD, Abbott RM, Rohrmann JrC, et al. Gastrointestinal hemangiomas: Imaging findings with pathologic correlation in pediatric and adult patients. American Journal Of Roentgenology 2001;177(5):1073-81.

17. Lawless ME, Lloyd KA, Swanson PE, et al. Lymphangiomatous lesions of the gastrointestinal tract: A clinicopathologic study and comparison between adults and children. Am J Clin Pathol 2015;144(4):563-9.

18. Deshpande A, Nelson D, Corless CL, et al. Leiomyoma of the gastrointestinal tract with interstitial cells of Cajal: A mimic of gastrointestinal stromal tumor. Am J Surg Pathol 2014;38(1):72-7.

19. Voltaggio L, Murray R, Lasota J, et al. Gastric schwannoma: A clinicopathologic study of 51 cases and critical review of the literature. Human pathology 2012;43(5):650-9.

20. Voltaggio L, Montgomery E. Gastric mesenchymal lesions other than gastrointestinal stromal tumor. Diagnostic Histopathology 2014;20(6):228-38.

21. Mekras A, Krenn V, Perrakis A, et al. Gastrointestinal schwannomas: A rare but important differential diagnosis of mesenchymal tumors of gastrointestinal tract. BMC Surgery 2018;18(1):47.

22. Faustino AV, Rama TF, Andrade MP, et al. A rare tumour, a singular indication: Sleeve gastrectomy in a morbidly obese septuagenarian with gastric schwannoma. Journal Of Surgical Case Reports 2020;2020(10):rjaa421. 